\title{
PENGARUH EFEKTIVITAS KINERJA TERHADAP PRODUKTIVITAS KERJA PETUGAS DISTRIBUSI REKAM MEDIS RAWAT JALAN DI RSUD CIBABAT CIMAHI
}

\author{
M. Dana Prihadi ${ }^{1}$ \\ danaprihadi@apikesbandung.ac.id \\ Akademi Perekam Medis Dan Informatika Kesehatan (Apikes) Bandung \\ Siska Meilani² \\ siskameilani@apikesbandung.ac.id \\ Akademi Perekam Medis Dan Informatika Kesehatan (Apikes) Bandung
}

\begin{abstract}
Abstrak
Kinerja terhadap produktivitas suatu pekerjaaan merupakan modal awal dalam memberikan hasil yang positif dan efektif pada suatu kegiatan bekerja. Tidak menutup kemungkinan baik buruknya hasil yang efektif itu adalah buah dari motivasi, gaji, kemampuan atau bahkan hubungan social pekerja tersebut. Tujuan dari penelitian ini adalah untuk mengetahui seberapa besar rata-rata efektivitas kinerja dan produktivitas kerja petugas distribusi rekam medis di RSUD Cibabat, untuk mengetahui seberapa besar pengaruh efektivitas kinerja terhadap produktivitas kerja petugas distribusi rekam medis RSUD Cibabat. Desain penelitian adalah kombinasi deskriptif dan penjelasan dengan jumlah responden adalah 11 orang. Hasil dari penelitian ini adalah tingkat rata - rata efektivitas kinerja petugas distribusi di RSUD Cibabat efektif, sedangkan rata-rata tingkat produktivitas karyawan adalah produktif. Efektivitas kinerja berpengaruh signifikan untuk produktivitas petugas, persamaan regresi adalah $Y=25,457+0,455 X$. Besarnya pengaruh kepuasan kerja terhadap produktivitas karyawan adalah 57,3\%, sedangkan sisanya 42,7\% dipengaruhi oleh variabel lain. Faktor penentu ketidakefektivitasan petugas distribusi rekam medis dapat diduga karena gaji dan finansal, kemampuan, hubungan kerja yang diterima kurang sesuai dengan tanggung jawab pekerjaan dan tingkat resiko yang dimliki dari pekerjaan tersebut. Sebaiknya untuk meningkatkan efektivitas kinerja melakukan pelatihan dan hubungan kerja yang maksimal, sistem perekrutan petugas yang lebih terarah sesuai dengan bidangnya, menciptakan kenyamanan lingkungan kerja secara team. Selain itu adalah evaluasi rumah sakit terhadap efektivitas kinerja petugas distribusi yang continue.
\end{abstract}

Kata Kunci : efektivitas kinerja, produktivitas kerja, distribusi rekam medis.

\section{Pendahuluan}

Rumah sakit merupakan salah satu organisasi yang bergerak di bidang kesehatan untuk memenuhi kebutuhan pelayanan kesehatan masyarakat di suatu wilayah. Sebuah Rumah Sakit akan memberikan pelayanan optimal manakala didukung oleh sumber daya yang berkualitas. Sumber daya yang dibutuhkan Rumah Sakit pun sangat beragam, salah satunya adalah sumber daya manusia. Sumber daya manusia merupakan unsur penting karena bersifat jasa dan tidak dapat disimpan sebagai persediaan, tetapi hanya diproduksi pada saat dikonsumsi karena sumber daya manusia merupakan aset utama dalam memberikan tenaga, potensi, kreativitas, dan usaha terhadap kemajuan Rumah Sakit tersebut. Dalam perkembangan teknologi yang pesat dan persaingan yang semakin ketat, maka rumah sakit dituntut untuk terus melakukan peningkatan kualitas pelayanannya (Depkes RI, 2008).

Perkembangan persaingan bisnis rumah sakit yang semakin kompetitif baik domestik maupun internasional mengharuskan organisasi mengelola sumber daya manusia mereka dengan baik karena karyawan merupakan aset berharga bagi organisasi untuk mencapai tujuan. Pengelolaan sumber daya manusia ini menjadi 
kewajiban yang harus dilakukan oleh perusahaan karena keberhasilan suatu organisasi bergantung pada peran sumber daya manusia yang dimiliki (Muhammad Fauzan, 2016). Manusia merupakan sumber daya paling vital dalam organisasi. Sumber daya manusia menunjang organisasi dengan tenaga, bakat, dan ide-ide kreatifitas yang dimilikinya. Betapapun sempurnanya sumber daya keuangan dan teknologi yang dimiliki, tanpa kualitas sumber daya manusia yang qualified maka organisasi tersebut sulit mencapai tujuannya (Deden Misbahudin Muayyad, 2016). Menurut Schuler et al (dalam Sutrisno, 2014), salah satu tujuan dari adanya manajemen sumber daya manusia adalah untuk memperbaiki tingkat produktivitas, memperbaiki kualitas kehidupan kerja, dan meyakinkan organisasi bahwa telah memenuhi aspek-aspek legal.

Pada era globalisasi saat ini perkembangan dan kemajuan di berbagai bidang selalu mengedepankan efektivitas kinerja para pegawai yang dapat menggerakkan sekaligus menjalankan roda organisasi. Dewasa ini perubahan demi perubahan dalam meningkatkan kualitas kerja pegawai selalu menjadi fokus utama dalam meningkatkan pelayanan prima bagi masyarakat atau pasien, hal ini dipandang penting guna meningkatkan kinerja para pegawai. Terciptanya efektivitas kinerja yang baik diharapkan mampu untuk dapat menjamin percepatan, kelancaran, pelayanan terhadap masyarakat secara baik dan tepat. Keterpaduan tugas dan fungsi penyelenggara dalam meningkatkan profesionalitas dan produktivitas kerja dalam sebuah organisasi juga harus diperhatikan. Efektivitas merupakan kemampuan untuk memilih tujuan yang tepat atau peralatan yang tepat untuk pencapaian tujuan yang telah ditetapkan (T. Hani Handoko, 2003). Kinerja merupakan hasil-hasil fungsi kegiatan atau pekerjaan seseorang atau kelompok dalam suatu organisasi yang dipengaruhi oleh berbagai faktor untuk mencapai tujuan organisasi dalam periode waktu tertentu (Tika, 2006). Produktivitas kerja merupakan perbandingan yang dimiliki baik secara perorangan ataupun tim di dalam organisasi tersebut (Hasibuan, 2010). Menurut (Sedarmayanti, 2001) produktivitas kerja adalah perbandingan antara hasil yang di capai (output) dengan keseluruhan sumber daya yang di gunakan (input). Dalam hal pengukuran produktivitas kerja, diperlukan suatu indikatorseperti kemampuan, berusaha meningkatkan hasil, semangat kerja, pengembangan diri, mutu, efisiensi (Sutrisno, 2014).

Observasi pendahuluan yang dilakukan, terdapat masalah yaitu masih banyak pegawai yang bekerja tidak sesuai keahliannya dan juga dalam penyediaan dan pengiriman berkas rekam medis ke poli mengalami ketelambatan sehingga mengakibatkan terhambatnya produktivitas optimal pada rumah sakit. Ketidakoptimalan tersebut apabila tidak segera ditangani dan berlangsung terus menerus dalam jangka waktu yang lama, akan mengakibatkan menurunnya jumlah kunjungan pasien yang berimbas turunnya pendapatan dan performa penilaian pasien terhadap rumah sakit.

\section{Metode Penelitian}

\subsection{Metode dan Desain Penelitian}

Metode yang penulis akan gunakan dalam penelitian ini adalah metode penelitian kuantitatif. Teknik pengambilan sampel pada umumnya dilakukan secara random, pengumpulan data menggunakan instrumen penelitian, analisis data bersifat kuantitatif/statistic inferensial dengan tujuan untuk menganalisis data sampel dan hasilnya diberlakukan untuk populasi. Statistik ini akan cocok digunakan bila sampel diambil dari populasi yang jelas, dan teknik pengambilan sampel dari populasi itu dilakukan secara random Sugiyono (2013). 


\subsection{Populasi, Sampel, dan teknik Sampling}

Populasi penelitian ini adalah keseluruhan petugas Rekam Medis bagian distribusi rawat jalan RSUD Cibabat. Mengingat jumlah petugas distribusi dan penyimpanan rekam medis sebanyak 11 orang maka dalam penelitian ini penulis akan menggunakan semua populasi untuk dijadikan sampel penelitian. Dengan demikian metode sampel dalam penelitian ini menggunakan teknik non probability.

\subsection{Teknik Dan Instrumen Pengumpulan Data}

Teknik yang digunakan dalam pengumpulan data ini yaitu dengan menggunakan metode observasi dan survey melalui kuesioner dengan model tertutup dimana telah disediakan jawaban yang dapat memberi gambaran tentang dimensi produktivitas serta untuk mengetahui kinerja petugas dan pengukuran dilakukan melalui skala linkert. Pengumpulan data adalah pengukuran dan pengamatan berbagai variable yang telah ditentukan dengan menggunakan alat dan metode yang telah ditentukan. Adapun teknik pengumpulan data yang penulis lakukan adalah: observasi, kuesioner, interview (wawancara), studi pustaka.

\subsection{Validasi dan reliabilitas Instrumen Pengumpulan Data}

\section{1) Uji Validasi}

Uji validitas dimaksudkan untuk mngetahui ketepatan dan kecermatan suatu alat ukur dalam melakukan fungsi ukurnya atau memberikan hasil ukur yang sesuai dengan menghitung korelasi antara masing-masing pertanyaan dengan skor total. Ada dua kemungkinan dalam melakukan perhitungan skor korelasi sebagai berikut, Jika r-hitung $\geq$ r-tabel atau jika nilai r-hitung lebih besar dari 0,3 maka item pernyataan tersebut valid. Jika r-hitung $\leq \mathrm{r}$-tabel atau jika nilai $r$-hitung lebih kecil dari 0,3 , maka item pernyataan tersebut tidak valid, sehingga diperlukan perbaikan ataupun pernyataan tersebut tidak dipakai lagi.

2) Uji Reliabilitas

Uji Reliabilitas adalah alat untuk mengukur suatu koesioner yang merupakan indikator dari variabel atau konstruk. Suatu kuesioner dikatakan reliabel atau handal jika jawaban seseorang terhadap pernyataan adalah konsisten atau stabil dari waktu ke waktu (Ghozali, 2012). Sedangkan uji Reliabilitas dimaksudkan untuk mengukur seberapa jauh responden memberikan jawaban yang konsisten terhadap kuesioner yang diberikan.

3) Uji t

Uji statistik t pada dasarnya menunjukkan seberapa jauh pengaruh satu variabel penjelas secara individual dalam menerangkan variasi variabel terikat. Pengujian ini bertujuan untuk menguji pengaruh variabel Kinerja Petugas dan Mutu Pelayanan.

\subsection{Teknik Pengolahan Data}

Data yang sudah terkumpul kemudian diolah dengan menggunakan metode SPSS. Adapun langkah-langkah yang ditempuh dalam pengolahan data adalah sebagai berikut: Pemeriksaan Data, Editing (processing), Tabulasi.

\subsection{Regresi linear sederhana}

Sugiyono (2010) digunakan oleh peneliti bila peneliti bermaksud meramalkan bagaimana keadaan (naik turunnya) variable dependen (kriterium), bila ada satu variable independen sebagai predictor dimanipulasi (dinaik turunkan nilainya). Persamaan yang diperoleh dari regresi sederhana adalah $Y=a+b \quad X y=$ adalah subjek nilai dalam variable terkait yang diprediksikan =harga $Y$ bila $X=0$ (harga konstan) $b=$ angka arah koefisien regresi $X=$ subjek pada variable bebas yang mempunyai nilai tertentu. 


\section{Hasil Penelitian Dan Pembahasan}

Berdasarkan hasil pengujian validitas dan reliabilitas yang diuraikan diatas penulis menyimpulkan bahwa keseluruhan jumlah pernyataan yang digunakan dalam penelitian ini sudah teruji valid dan reliable, sehingga seluruh instrument pertanyaan layak digunakan sebagai alat ukur penelitian

Tabel 1. Data Usia Responden

\begin{tabular}{|l|l|l|l|l|l|}
\hline \multicolumn{2}{|c|}{} & Frequency & Percent & $\begin{array}{l}\text { Valid } \\
\text { percent }\end{array}$ & $\begin{array}{l}\text { Cumulative } \\
\text { percent }\end{array}$ \\
\hline Valid & $\begin{array}{l}31^{\text {th }} \\
40^{\text {th }}\end{array}$ & 9 & 81,8 & 81,1 & 81,1 \\
\cline { 2 - 6 } & $>40^{\text {th }}$ & 2 & 18,2 & 18,2 & 100,0 \\
\cline { 2 - 6 } & Total & 11 & 100,0 & 100,0 & \\
\hline
\end{tabular}

Tabel 2. Data Jenis Kelamin Responden

\begin{tabular}{|l|l|l|l|l|l|}
\hline \multicolumn{2}{|c|}{} & Frequency & Percent & $\begin{array}{l}\text { Valid } \\
\text { percent }\end{array}$ & $\begin{array}{l}\text { Cumulative } \\
\text { percent }\end{array}$ \\
\hline \multirow{3}{*}{ Valid } & Pria & 10 & 90,9 & 90,9 & 90,9 \\
\cline { 2 - 6 } & Wanita & 1 & 9,1 & 9,1 & 100,0 \\
\cline { 2 - 6 } & Total & 11 & 100,0 & 100,0 & \\
\hline
\end{tabular}

Tabel 3. Data Masa Kerja Responden

\begin{tabular}{|l|l|l|l|l|l|}
\hline \multicolumn{2}{|c|}{} & Frequency & Percent & $\begin{array}{l}\text { Valid } \\
\text { percent }\end{array}$ & $\begin{array}{l}\text { Cumulative } \\
\text { percent }\end{array}$ \\
\hline \multirow{3}{*}{ Valid } & $1^{\text {th }}-5^{\text {th }}$ & 2 & 18,2 & 18,2 & 18,2 \\
\cline { 2 - 6 } & $>10^{\text {th }}$ & 9 & 81,8 & 81,8 & 100,0 \\
\cline { 2 - 6 } & Total & 11 & 100,0 & 100,0 & \\
\hline
\end{tabular}

Tabel 4. Data Hasil Uji Validitas

\begin{tabular}{|l|l|l|l|l|}
\hline Variable & Item Pernyataan & r Hitung & r Tabel & Ket \\
\hline $\begin{array}{l}\text { Efektivitas } \\
\text { Kinerja }\end{array}$ & $\begin{array}{l}\text { Kemampuan } \\
\text { Menyesuaikan Diri (X1) }\end{array}$ & 0,796 & 0,5214 & Valid \\
\cline { 2 - 5 } & $\begin{array}{l}\text { Kemampuan } \\
\text { Menyesuaikan Diri (X2) }\end{array}$ & 0,796 & 0,5214 & Valid \\
\cline { 2 - 5 } & $\begin{array}{l}\text { Kemampuan } \\
\text { Menyesuaikan Diri (X3) }\end{array}$ & 0,796 & 0,5214 & Valid \\
\cline { 2 - 5 } & Prestasi Kerja (X4) & 0,789 & 0,5214 & Valid \\
\cline { 2 - 5 } & Prestasi Kerja (X5) & 0,761 & 0,5214 & Valid \\
\cline { 2 - 5 } & Prestasi Kerja (X6) & 0,846 & 0,5214 & Valid \\
\cline { 2 - 5 } & Kepuasan Kerja (X7) & 0,836 & 0,5214 & Valid \\
\cline { 2 - 5 } & Kepuasan Kerja (X8) & 0,838 & 0,5214 & Valid \\
\cline { 2 - 5 } & Kepuasan Kerja (X9) & 0,711 & 0,5214 & Valid \\
\cline { 2 - 5 } & Kualitas (X10) & 0,869 & 0,5214 & Valid \\
\cline { 2 - 5 } & Kualitas (X11) & 0,816 & 0,5214 & Valid \\
\cline { 2 - 5 } & Kualitas (X12) & 0,816 & 0,5214 & Valid \\
\cline { 2 - 5 } & Penilaian Oleh Pihak Luar (X13) & 0,785 & 0,5214 & Valid \\
\cline { 2 - 5 } & Penilaian Oleh Pihak Luar (X14) & 0,829 & 0,5214 & Valid \\
\cline { 2 - 5 } & Penilaian Oleh Pihak Luar (X15) & 0,829 & 0,5214 & Valid \\
\cline { 2 - 5 } & Kemampuan/ Kompetensi (Y1) & 0,647 & 0,5214 & Valid \\
\cline { 2 - 5 } & Kemampuan/ Kompetensi & 0,647 & 0,5214 & Valid \\
\hline \multirow{2}{*}{\begin{tabular}{l} 
Krodukja \\
\cline { 2 - 5 }
\end{tabular}}
\end{tabular}


Berdasarkan tabel 4. tersebut dapat diketahui bahwa terdapat 15 item pertanyaan dari variabel efektivitas kinerja $(\mathrm{X})$ dan 12 pertanyaan dari variabel produktivitas kerja $(\mathrm{Y})$. Semua item pertanyaan tersebut memiliki nilai $r$ hitung $>r$ tabel atau besarnya nilai sig. (2-tailed) $<0,05$ artinya semua pertanyaan tersebut memiliki korelasi dengan skor totalnya, sehingga semuanya valid.

Tabel 5. Data Hasil Uji Reabilitas

\begin{tabular}{|l|l|l|l|}
\hline Variable & $\begin{array}{l}\text { Reliabilitas } \\
\text { Koefisien }\end{array}$ & Alpha & Keterangan \\
\hline Efektivitas Kinerja (X) & 15 Item & 0,958 & Reliable \\
\hline Produktivitas Kerja (Y) & 12 Item & 0,890 & Reliable \\
\hline
\end{tabular}

Dari table 5. di atas dapat dilihat bahwa cronbach's alpha dari variabel X 0,958 lebih besar 0,60, maka kuesioner variabel $X$ reliabel. Kemudian cronbach's alpha dari variabel Y 0,890 lebih besar dari 0,60 maka kuesioner dari variabel Y reliabel.

Tabel 6. Data Hasil Uji Normalitas

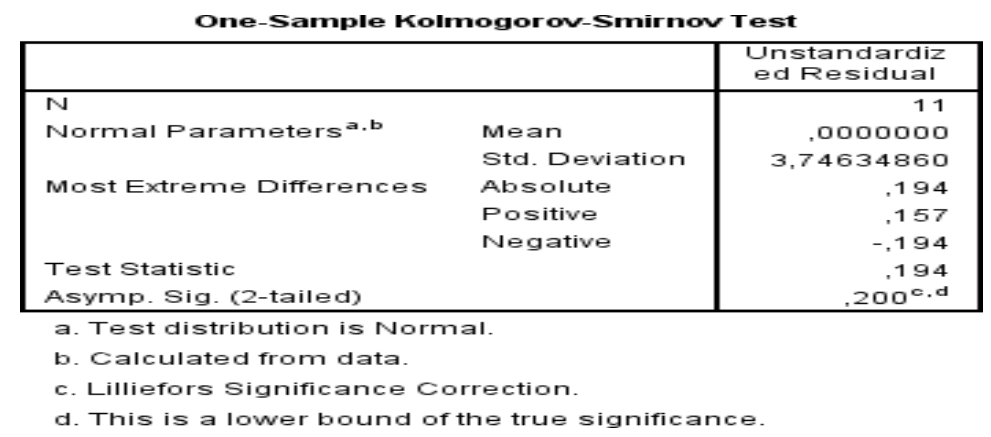

Berdasarkan hasil uji normalitas diketahui nilai signifikan 0,200 >0,05 maka dapat disimpulkam bahwa nilai residual berdistribusi normal.

Tabel 7. Data Hasil Deskriptif Statistik

Descriptive Statistics

\begin{tabular}{|l|r|r|r|r|r|}
\hline & \multicolumn{1}{|c|}{ N } & Minimum & Maximum & Mean & Std. Deviation \\
\hline EFEKTIVITAS KINERJA & 11 & 39 & 66 & 49,73 & 9,540 \\
Valid N (listwise) & 11 & & & & \\
\hline
\end{tabular}

Berdasarkan tabel di atas, nilai minimum kepuasan kerja petugas distribusi rekam medis berada pada nilai 39 dan maksimum berada pada nilai 66. Demikian dengan rerata tingkat efektivitas kinerja berada pada nilai 49,73, artinya secara keseluruhan efektivitas kinerja petugas distribusi termasuk dalam kategori efektif.

Tabel 8. Data Hasil Deskriptif Statistik

Descriptive Statistics

\begin{tabular}{|l|r|r|r|r|r|}
\hline & \multicolumn{1}{|c|}{ N } & Minimum & Maximum & Mean & Std. Deviation \\
\hline PRODUKTIVITAS KERJA & 11 & 40 & 57 & 48,09 & 5,735 \\
Valid N (listwise) & 11 & & & & \\
\hline
\end{tabular}


Dari tabel tersebut terlihat nilai minimum produktivitas kerja petugas distribusi berada pada nilai 40 dan maksimum berada pada nilai 57. Dengan demikian, rata-rata tingkat produktivitas kerja petugas distribusi berada pada nilai 48,09, yang artinya secara keseluruhan tingkat produktivitas kerja petugas distribusi termasuk dalam kategori produktif.

Tabel 9. Data Hasil Analisis Regresi Linear Berganda

ANOVA ${ }^{a}$

\begin{tabular}{|ll|r|r|r|r|c|}
\hline Model & & \multicolumn{1}{c|}{$\begin{array}{c}\text { Sum of } \\
\text { Squares }\end{array}$} & \multicolumn{1}{c|}{ df } & Mean Square & F & Sig. \\
\hline 1 & Regression & 188,558 & 1 & 188,558 & 12,091 &, $007^{\mathrm{b}}$ \\
& Residual & 140,351 & 9 & 15,595 & & \\
& Total & 328,909 & 10 & & & \\
\hline
\end{tabular}

a. Dependent Variable: PRODUKTIVITAS KERJA

b. Predictors: (Constant), EFEKTIVITAS KINERJA

Dari output tersebut diketahui bahwa nilai $\mathrm{F}$ hitung $=12,091$ dengan tingkat signifikansi sebesar 0,007 <0,05, maka model regresi dapat dipakai untuk memprediksi variabel produktivitas kerja atau dengan kata lain ada pengaruh variabel efektivitas kinerja $(\mathrm{X})$ terhadap produktivitas kerja $(\mathrm{Y})$.

Tabel 10. Data Hasil Analisis Regresi Linear Sederhana

Coefficients $^{\mathrm{a}}$

\begin{tabular}{|c|c|c|c|c|c|c|}
\hline \multirow{2}{*}{\multicolumn{2}{|c|}{ Model }} & \multicolumn{2}{|c|}{ Unstandardized Coefficients } & \multirow{2}{*}{$\begin{array}{c}\begin{array}{c}\text { Standardized } \\
\text { Coefficients }\end{array} \\
\text { Beta }\end{array}$} & \multirow[b]{2}{*}{$t$} & \multirow[b]{2}{*}{ Sig. } \\
\hline & & $\mathrm{B}$ & Std. Error & & & \\
\hline \multirow[t]{2}{*}{1} & (Constant) & 25,457 & 6,617 & & 3,847 &, 004 \\
\hline & EFEKTIVITAS KINERJA &, 455 &, 131 &, 757 & 3,477 &, 007 \\
\hline
\end{tabular}

a. Dependent Variable: PRODUKTIVITAS KERJA

Berdasarkan data table 10. Di atas dapat dijelaskan konstanta sebesar 25,457 mengandung arti bahwa nilai konstanta variabel produktivitas kerja adalah sebesar 25 , 457. Koefesien regresi $X 0,455$ menyatakan bahwa setiap penambahan $1 \%$ nilai efektivitas kinerja, maka nilai produktivitas bertambah sebesar 0,455. Koefesien regresi tersebut bernilai positif, sehingga dapat dikatakan bahwa arah pengaruh varabel $X$ terhadap Y adalah positif.

Tabel 11. Data Hasil Uji t

\begin{tabular}{|c|c|c|c|c|c|c|}
\hline \multicolumn{7}{|c|}{ Coefficients $^{\mathrm{a}}$} \\
\hline \multirow[b]{2}{*}{ Model } & & \multicolumn{2}{|c|}{ Unstandardized Coefficients } & $\begin{array}{l}\text { Standardized } \\
\text { Coefficients }\end{array}$ & \multirow[b]{2}{*}{$t$} & \multirow[b]{2}{*}{ Sig. } \\
\hline & & $B$ & Std. Error & Beta & & \\
\hline 1 & (Constant) & 25,457 & 6,617 & & 3,847 &, 004 \\
\hline & EFEKTIVITAS KINERJA & .455 &, 131 &, 757 & 3,477 &, 007 \\
\hline
\end{tabular}

Diketahui nilai signifikan untuk pengaruh $\mathrm{X}$ terhadap $\mathrm{Y}$ adalah sebesar 0,007< 0,05 dan nilai $\mathrm{t}$ hitung 3,477 > t tabel 2,262 sehingga dapat disimpulkan bahwa Ha diterima yang berarti terdapat pengaruh variabel $X$ terhadap variabel $Y$. 
Hasil pengolahan data demografi responden menunjukan secara keseluruhan usia kerja petugas distribusi rekam medis RSUD Cibabat didominasi oleh usia kerja yang masih produktif yaitu usia 31-40 tahun. Jika produktivitas kerja terus meningkat maka profitabilitas rumah sakit pun dapat diindikasi akan meningkat pula. Selanjutnya, riwayat pendidikan didominasi oleh lulusan SMA dan diikuti oleh lulusan D3. Masa kerja petugas distribusi didominasi oleh petugas dengan masa kerja lebih dari 10 tahun diikuti oleh masa kerja 1-5 tahun. Faktor penentu produktivitas dalam studi ini adalah kemampuan, tanggung jawab, efisiensi, pengembangan, dan evaluasi. Hasil pengolahan data menunjukan bahwa secara nyata faktor penentu efektivitas kinerja berpengaruh terhadap produktivitas kerja petugas distribusi rekam medis RSUD Cibabat. Hal ini seiring pula dengan hasil yang menunjukan bahwa pengaruh tingkat efetivitas kinerja terhadap produktivitas berpengaruh sebesar $57,3 \%$. Nilai ini menunjukan pengaruh yang kuat. Faktor penentu ketidakefektivitasan petugas distribusi rekam medis dapat diduga karena gaji dan finansal, kemampuan, hubungan kerja yang diterima kurang sesuai dengan tanggung jawab pekerjaan dan tingkat resiko yang dimiliki dari pekerjaan tersebut. Umumnya, petugas fresh graduated sangat rentan dengan resistensi pekerjaan. Dimana kebanyakan dari mereka masih mencari pengalaman dalam menentukan apa yang sebenarnya mereka inginkan. Selain itu relevansi pekerjaan biasa terjadi tidak sesuai dengan background keilmuan yang mereka miliki sebelumnya. Sehingga mereka akan menerima beban pekerjaan yang lebih dalam melakukan pekerjaannya dan menjadikan produktivitas menjadi tidak maksmal. Jika petugas tidak dapat menghasilkan produktivitas yang maksimal maka akan menjadikan beban operasional rumah sakit yang meningkat. Salah satunya adalah beban gaji petugas. Salah satu rekomendasi yang dapat dilakukan oleh rumah sakit adalah dengan melakukan pelatihan dan hubungan kerja yang maksimal, system perekrutan petugas yang lebih terarah sesuai dengan bidangnya, menciptakan kenyamanan lingkungan kerja secara team. Selain itu adalah evaluasi rumah sakit terhadap efektivitas kinerja petugas distribusi yang continue.

\section{Kesimpulan}

1) Rerata tingkat efektivitas kinerja petugas distribusi rekam medis RSUD Cibabat mencapai tingkat efektif. Sedangkan tingkat produktivitas kerja petugas distribusi rekam medis dapat dikategorikan produktif.

2) Efektivitas kinerja $(X)$ berpengaruh signifikan terhadap produktivitas kerja petugas rekam medis $(\mathrm{Y})$ yang dibuktikan dengan nilai signifikansi dibawah 0,05 dan nilai thitung $>$ ttabel. Persamaan regresi yang didapatkan adalah $Y=25,457+0,455 X$. Besarnya pengaruh Efektivitas kinerja terhadap produktivitas kerja pertugas distribusi rekam medis RSUD Cibabat dilihat dari besarnya nilai R Square yang diperoleh yakni sebesar 57,3\%, sedangkan sisanya dipengaruhi oleh variabel lain yang tidak dimasukan dalam model ini.

3) Faktor ketidakefektivitasan kinerja petugas distribusi rekam medis dapat diduga karena gaji dan finansal, kemampuan, hubungan kerja yang dterima kurang sesuai dengan tanggung jawab pekerjaan dan tingkat resiko yang dimliki dari pekerjaan tersebut.

4) Upaya untuk meningkatkan efektivitas kinerja melakukan pelatihan dan hubungan kerja yang maksimal, sistem perekrutan petugas yang lebih terarah sesuai dengan bidangnya, menciptakan kenyamanan lingkungan kerja secara team. Selain itu adalah evaluasi rumah sakit terhadap efektivitas kinerja petugas distribusi yang continue 


\section{Daftar Pustaka}

Depkes. 2008. Pencegahan dan Penatalaksanaan Asfiksia Neonatorum. Jakarta: Dinkes RI. hal 8-6.

Fauzan, Muhammad. 2016. Pengaruh Kepuasan Kerja Dan Komitmen Organisasi Terhadap Turnover Intention. Yogyakarta.

Ghozali, I. 2012. Imam Ghozali. 2012. Aplikasi analisis multivariate dengan program ibm spss, 20.

Handoko, T.Hani. 2003. Manajemen Personalia dan Sumber Daya Manusia. Yogyakarta: BPEEYogyakarta.

Hasibuan, S.P Malayu. 2010. Manajemen Sumber Daya Manusia. Jakarta: Bumi Aksara.

Misbahudin Muayyad, Deden. 2016. Pengaruh Kepuasan Kerja Terhadap Produktivitas Kerja Pegawai Bank Syariah X Kantor Wilayah II. Jakarta. Universitas Trisakti.

Sedarmayanti, (2009). Sumber Daya Manusia dan Produktivitas Kerja. Bandung : Mandar Maju. Sugiyono, 2013. Metodologi Penelitian Kuantitatif, Kulitatif dan RD. CV Alfa Beta : Bandung.

Sutrisno, Edy. 2014. Manajemen Sumber Daya Manusia. Edisi- 6. Jakarta: Pranada Media Group.

Tika, P. 2006. Budaya Organisasi dan Peningkatan Kinerja Perusahaan. Jakarta: Bumi Aksara. 